The Problem of Normative Authority in Kant, Hegel, and Nietzsche

\author{
Paul Katsafanas \\ Forthcoming in Nietzsche's Engagements with Kant, Volume I: Ethics, \\ edited by Tom Bailey and João Constâncio.
}

Abstract:

Kant and Hegel agree that normative claims are justified only if they are manifestations of freedom. Yet they develop this idea in strikingly different ways: Kant attempts to derive substantive ethical content from a formal notion of autonomy, whereas Hegel argues that this approach fails. I argue that Nietzsche develops a theory of normativity that incorporates aspects from both Kant and Hegel. Like Hegel, Nietzsche denies that Kant can derive any content from the notion of autonomy. However, Nietzsche departs from Hegel in arguing that one norm can be extracted from the bare idea of freedom, independently of any facts about the particular system of values, practices, and institutions that the individual inhabits. This norm is will to power. Its connection to freedom and its independence from extant social norms gives it a position outside of our current system of ethical judgments, making possible a radical critique of these judgments. Developing these points, I argue that Nietzsche develops a theory of normative authority that proceeds, in part, by reconciling the most compelling aspects of the Kantian and Hegelian accounts—aspects that have seemed, to many interpreters, to be incompatible. This results in a novel account of normative authority. 
The Problem of Normative Authority in Kant, Hegel, and Nietzsche

\author{
Paul Katsafanas
}

In quite different ways, Kant and Hegel argue that normative claims are justified only if they are manifestations of freedom. That is, claims such as "murder is wrong," "you have reason not to lie," or "you should take the means to your ends" have authority over us only if these claims issue from or are preconditions for autonomous agency. Beyond this point of agreement, however, the differences between Kant and Hegel may seem enormous. Kant argues that autonomous agency yields a commitment to acting on the Categorical Imperative, which in turn generates specific claims about which actions are permissible and which are forbidden. Hegel rejects this idea, arguing that we cannot extract any determinate claims about what there is reason to do from a merely formal conception of autonomous agency. Instead, claims about what there is reason to do are inextricably linked to the practices and institutions of our historical milieu — though, in order to be justified, these practices and institutions must themselves be realizations of freedom.

Proponents of each theory each levy critiques at the other. Hegelians charge Kantians with relying on an excessively formal and ultimately contentless conception of autonomy, which is too attenuated to generate substantive normative conclusions. Kantians charge Hegelians with relying on an excessively substantive, concrete theory, which is so mired in the particularities of our current evaluative framework that it cannot even make space for a comprehensive critique of this framework.

While Kantians and Hegelians have developed sophisticated responses to these charges, I contend that there is an element of truth in each of the critiques. One goal of this essay is to sketch 
these potential problems, by showing how certain aspects of the Kantian and Hegelian theories of normative authority ${ }^{1}$ are prone to substantial difficulties. However, my primary goal is to demonstrate that we can overcome these difficulties by turning to an unexpected source: the work of Nietzsche. I argue that Nietzsche provides an account of normative authority that incorporates seemingly incompatible elements of the Kantian and Hegelian accounts. ${ }^{2}$ In so doing, his work reveals the potential structure of a fully satisfying account of normative authority. Thus, attending to the dispute between Kant and Hegel—and the solution that I argue is offered by Nietzscheenables us to make progress on a central topic in ethics: the relationship between freedom and normative authority.

The essay comprises four sections. Section One offers a brief review of Kant's attempt to explain normative authority in terms of autonomy. Section Two reconstructs Hegel's critique of Kant and introduces Hegel's alternative theory. Section Three turns to Nietzsche, arguing that Nietzsche accepts the most appealing elements of the Kantian and Hegelian accounts. Unfortunately, though, these elements seem to be incompatible with one another. Accordingly,

\footnotetext{
${ }^{1}$ I will use the phrase "theory of normative authority" to refer to an explanation of what makes normative claims legitimately binding for us. For example, "murder is wrong" and "eating vegetables is wrong" both purport to be claims according to which we should regulate our actions, but presumably the former is legitimate or justified in a way that the latter is not. A theory of normative authority explains why this is so.

${ }^{2}$ I do not aim to establish that Nietzsche self-consciously envisioned his project as reconciling Kantian and Hegelian elements. Rather, my aim is simply to show that Nietzsche's project does, in fact, reconcile these elements. However, my approach does invite a question: while it is well known that Nietzsche was deeply engaged with Kant, how thoroughly did he know Hegel's works? There is evidence that Nietzsche was familiar with Hegel's work. In a letter of 1865, Nietzsche mentions that he is studying one of Hegel's texts (he doesn't say which text); in 1873, he reads Hegel's Lectures on the Philosophy of History. Nietzsche also encountered extensive treatments of Hegel through secondary sources: he attended and thought highly of Jakob Burckhardt's 1870 lectures, which discussed Hegel at length, and he studied F.A. Lange's and Schopenhauer's expositions of Hegel. Nietzsche had enough familiarity with Hegel to reject Schopenhauer's reading, chiding Schopenhauer for his "unintelligent rage" against Hegel (BGE 204). In later works Nietzsche praises Hegel, calling him a "genius" and listing him as one of only three philosophers who produced a "great insight" (BGE 252 and GS 357). For discussions of Hegel's influence on Nietzsche, see Brobjer (2008), Houlgate (2004), Dudley (2007).
} 
Section Four explains how Nietzsche's theory of normative authority resolves the tensions between these elements of the Kantian and Hegelian accounts. In particular, Nietzsche—with Hegel—denies that we can derive a substantive ethic from the formal idea of autonomy. However, pace Hegel and with Kant, Nietzsche argues that we can extract one normative principle from this formal idea. This normative principle, which Nietzsche labels "will to power," can then be used to critique the values and norms embodied in our social institutions and practices. Unlike Kant, however, Nietzsche denies that this principle extracted from the notion of autonomy can by itself generate any determinate content; on the contrary, it generates substantive normative conclusions only when brought to bear on the norms that are present in our social institutions and practices. I argue that the resultant theory overcomes both the charges that Hegelians level at Kantians and those that Kantians levy at Hegelians. In so doing, it yields a new and fruitful solution to the problem of normative authority.

\section{KANT ON THE PROBLEM OF NORMATIVE AUTHORITY}

Normative claims invite the question of why they should hold sway over us. Kant proposed to answer this question by tying the authority of norms to our own activity: norms hold sway over us because we impose them on ourselves.

Thus, Kant claims that the will must view itself "as the author of its principles independently of alien influences" (G 4:448). If we consider a normative principle—or, as Kant puts it, a "law" that constrains the will, then the will must give itself this law:

Hence the will is not merely subject to the law, but subject to it in such a way that it must be regarded as also giving law to itself and just because of this as first subject to the law (of which it can regard itself as the author). (G 4:431)

Anything less would render the will heteronomous, or unfree: 
If the will seeks the law that is to determine it...in the character of any of its objects- the result is always heteronomy. In that case the will does not give itself the law, but the object does so in virtue of its relation to the will. (G 4:441)

Thus, according to Kant, no external authority binds me to normative principles; rather, I bind myself to principles, and therein arises their claim to authority over me.

But how, exactly, is an appeal to self-imposition supposed to answer the normative problem? It might seem that if you impose a principle on yourself, then its authority will have been legitimated-because, after all, you impose it on yourself. However, it might equally well seem that if you impose a principle on yourself, then its authority disappears—because, after all, you can remove it as easily as you imposed it.

There is a tension here. A normative principle is something that can constrain one's will. However, if we attempt to explain the constraining authority of principles in terms of the will's own operations, then it seems that the alleged constraint disappears: if I bind myself by a principle, then I can also unbind myself, in which case I was never really bound at all.

This is a point that occupied a central position in nineteenth-century discussions of value. Consider a passage from Hegel's Philosophy of Right, in which Hegel considers the view that normative authority arises from the agent's own acts of will:

This implies that objective goodness is merely something constructed by my conviction, sustained by me alone, and that I, as lord and master, can make it come and go. As soon as I relate myself to something objective, it ceases to exist for me, and so I am poised above an immense void, conjuring up shapes and destroying them. (PR 140A)

Hegel here argues that if normative authority arose from an agent's acts of will, then norms would not appear to the agent as objective constraints. Rather, the norms would appear as empty, ephemeral shapes - for the agent could rescind the normative principle's authority as easily as she 
could bestow it. In sum, the idea that we "create" normative authority has no content, if the norms cannot constrain us.

In sum, Kant's idea seems to be that, if you make a norm for yourself, then of course it binds you, for you are its author. But Hegel argues for the opposite conclusion: if you make a norm for yourself, then of course it cannot bind you, for its alleged authority is dependent on you. To the extent that norms are genuinely self-imposed, they lose any authority to constrain us; they constrain us no more than our desires and whims do. Thus, the attempt to explain normative authority in terms of self-imposition runs the risk of collapsing the distinction between norm and whim.

Kant is, of course, aware of this potential problem, and has a way of trying to solve it. He claims that although the authority of norms is explained by the fact that we impose them on ourselves, the content of these norms is not up to us: the injunction "be autonomous!" imposes determinate constraints on what can be willed. The core idea is that in order to impose norms on ourselves at all, there are certain standards to which we become inescapably committed.

The general form of Kant's argument is familiar: we are committed to acting autonomously. Acting autonomously requires acting on a law or principle. The law cannot be hypothetical, i.e., tied to the realization of some goal or the satisfaction of some inclination, because the will would then be determined to action by something external to itself (i.e., an inclination or goal). Instead, the law must be categorical; it must be unconditionally valid. Kant states the content of this law as follows: "act only in accordance with that maxim through which you can at the same time will that it become a universal law" (G 4:421). He argues that this law—the Categorical Imperative-rules out certain actions, thereby yielding determinate constraints on permissible actions. So, the formal conception of freedom yields a substantive or contentful conception of which norms we are committed to acting upon.

This is why Kant, if his argument were successful, would have the resources to respond to the Hegelian objection. We cannot simply bind and unbind ourselves with any norms we happen to 
fancy; rather, although we impose norms on ourselves, these norms constrain us in a way that is not up to us- for which norms we impose on ourselves is not fully up to us.

\section{HEGEL ON THE PROBLEM OF NORMATIVE AUTHORITY}

This discussion of Kant and Hegel brings to light a criterion of adequacy on a successful account of normative authority: if we are to explain normative authority in terms of self-imposed commitments, then there must be determinate constraints on the content of these commitments. In Section 2.1, I explain why Hegel thinks that Kant's theory is incapable of meeting this criterion of adequacy. Section 2.2 sketches Hegel's alternative solution to the problem of normative authority. I argue that the core difference between Kant and Hegel on normative authority is this: whereas Kant thinks we derive norms from the idea of freedom, Hegel thinks we use freedom not to derive norms, but to assess norms.

\subsection{HegEL'S OBJECTION TO KANT}

Consider an old and familiar criticism: Kant's formal description of autonomy, as willing in accordance with the Categorical Imperative, does not yield any substantive results. Hegel was the first to levy this objection: he famously claims that Kant's view operates with an exceedingly "formal" or "abstract" conception of autonomy, which renders the theory an "empty formalism" (PR 135). There is controversy regarding the exact way in which Hegel's formalism objection should be interpreted, but on the most common interpretation, Hegel is claiming that Kant's universalization procedure does not yield any determinate conclusions. ${ }^{3}$

\footnotetext{
${ }^{3}$ Wood (1990) presents a helpful survey of several other possible readings. See also "Hegel's Ethical Rationalism," in Pippin (1997).
} 
To see what Hegel has in mind, consider one of Kant's applications of the Categorical Imperative in the Critique of Practical Reason. Kant asks us to consider a case in which I have been given some money to hold as a deposit, the individual making the deposit has died, and no record of the deposit exists. I ask myself whether I can keep this money for myself rather than reporting it to the deceased's heirs. Kant claims that we can apply the Categorical Imperative by asking whether the following principle could be willed as a universal law: "that everyone may deny a deposit of which no one can produce a proof." He claims that it cannot, for "I at once become aware that such a principle, viewed as a law, would annihilate itself, because the result would be that there would be no deposits" (C2 5:27-28). In other words, this maxim fails the universalization test, because if it were universalized then the institution of making deposits would disappear, and it would therefore no longer be possible to act on the maxim.

Hegel objects, arguing that

The absence of property contains in itself just as little contradiction as the non-existence of this or that nation, family, etc., or the death of the whole human race. But if it is already established on other grounds and presupposed that property and human life are to exist and be respected, then indeed it is a contradiction to commit theft or murder; a contradiction must be a contradiction of something, i.e. of some content presupposed from the start as a fixed principle. (PR 135R)

Hegel agrees with Kant that if the maxim of stealing deposits (or, more generally, property) in order to enrich oneself were universalized, the institution of deposit-making would disappear. However, Hegel claims that unless we presuppose, as a fixed principle, that deposits (or, more generally, property) should exist, this generates no contradiction at all.

The general point is well put in the Phenomenology: 
It would be strange, too, if tautology, the principle of contradiction, which is admitted to be only a formal principle for the cognition of theoretical truth, i.e., something which is quite indifferent to truth and falsehood, were supposed to be more than this for the cognition of practical truth. (PhG 431)

In other words, no one thinks that a contradiction test can tell us which theoretical beliefs are true. The beliefs "it is raining here" and "it is not raining here" are contradictory, so we know that they cannot both be true; but we cannot conclude, from the mere fact that they are contradictory, which one is true. Hegel's central point is that it is odd to think that things would be different in the practical realm. As the property case illustrates, certain maxims will generate contradictions with the institution of property; but this does not tell us whether the maxim is immoral or the institution of property is immoral. To make that judgment-to move from the idea that two propositions are contradictory to the idea that one of them is correct-we need to appeal to some independent grounds for determining what is moral.

This is why Hegel criticizes the idea of self-imposed constraints: he understands Kant as offering a merely formal criterion, which fails to generate any substantive constraints on what can be willed. ${ }^{4}$ If this objection is correct, then Kant's attempted derivation of substantive norms from the formal conception of autonomy runs afoul of the criterion of adequacy discussed above: the demand for autonomy does not yield any determinate constraints, and therefore collapses the distinction between norms and whims.

\footnotetext{
${ }^{4}$ Kantians argue that this objection is based on a misunderstanding: the contradiction does not depend on the idea that any particular institutions or practices should exist. Rather, the contradiction arises because the agent is attempting to act upon a maxim that, once universalized, would no longer be efficacious for its intended purpose. For an interpretation of this form, see Korsgaard (1996) and Wood (1990).
} 


\subsection{Hegel's Alternative to the Kantian STRATEgy}

These criticisms notwithstanding, Hegel does not think that Kantian morality should be completely abandoned. Rather, he characteristically argues that the failures of Kantian morality point us toward a more encompassing understanding of normativity —an understanding that resolves the problems to which Kantian morality succumbs.

Although Hegel agrees with Kant that normative considerations are authoritative only if they can be viewed as products of freedom, Hegel interprets this requirement in a different way than does Kant. ${ }^{5}$ To bring out the differences between Kant and Hegel, let's focus on two questions:

(1) What is the object of assessment?

(2) How is the assessment conducted?

Kant's answers to the two questions are clear: the agent assesses her maxims, and the assessment consists in determining whether the maxim passes the Categorical Imperative test. For Hegel, however, the answers are considerably more complex. First, the individual does not assess maxims, but social institutions and practices. Second, the individual does not attempt to show that these institutions and practices are consistent with or derivable from some additional, external standard. Rather, she attempts to show that they are institutions or practices that make freedom possible. Let me explain.

With regard to the first point, Hegel famously argues that the agent's freedom can be achieved only within and through certain social institutions and practices: simply put, I realize my freedom by conforming to the ethical practices of my society. As Hegel puts it, "only that will

\footnotetext{
${ }^{5}$ Hegel claims that the Philosophy of Right's central task is to show how "the system of right is the realm of actualized freedom" (PR 4). He emphasizes this point throughout the book, writing that "ethicality is the idea of freedom as the living good that has its knowing, willing, and, through its acting, its actuality, in self-consciousness...." (PR 142), and "the ethical is the system of these determinations of the idea; this is what constitutes its rationality. In this way it is freedom..." (PR 145).
} 
which obeys the law is free" (VG 115/97). However, not just any set of institutions and practices will enable individuals to realize their freedom. Consider a simple example: if the laws and institutions of my society condemn me to a life of slavery, I will not be able fully to realize my freedom by conforming to those laws and institutions. Thus, Hegel claims that we can ask, of any set of social institutions or practices, whether they enable all individuals to realize their freedom. The institutions count as "rational," in Hegel's terminology, or "justified," in ours, if they meet this condition, making it possible for all individuals to realize themselves as self-determined entities. ${ }^{6}$ Moreover, the institutions and practices must be such that subjects are not only in fact free, but are also capable of recognizing their own freedom. That is, individuals must be able to view these institutions and practices as expressions of their own wills, so that participation in them is conceived as free activity. ${ }^{7}$ In The Philosophy of Right, Hegel argues that three modern social institutions- the family, civil society, and the liberal state-jointly fulfill these conditions (PR 157ff.). ${ }^{8}$

So, this is the first difference between Kant and Hegel: rather than assessing individual maxims, Hegel assesses our social institutions and practices, asking whether they are realizations of freedom. This brings us to the second question: how, exactly, is this Hegelian assessment to be

\footnotetext{
${ }^{6}$ Hegel writes, "Within the state, rationality consists concretely - in terms of its content - in the unity of objective freedom (i.e., of universal substantial willing) and subjective freedom (i.e., of the individual human's knowing and willing, which seeks its particular ends)" (PR 258). In several passages, he emphasizes that society must enable the freedom of all individuals. For example, he writes that society requires the "well-being of all" (PR 125, emphasis added), and he argues that it is necessary that "every individual's livelihood and well-being be treated and actualized as rightful" (PR 230).

${ }^{7}$ Thus, after writing, "Only that will which obeys the law is free," Hegel continues, "for it obeys itself and is self-sufficient and therefore free" (VG 115/97). Elsewhere, he puts the point as follows: "the laws and powers of ethical substance are not something alien to the subject. Instead, the subject bears witness to them as to its own essence, within which it has its feelings of being a self, within which it lives as in its own element, an element it does not distinguish from itself' (PR 147; cf. PR 258).

${ }^{8}$ The full argument for these claims occupies PR 157-360. See especially PR 157-8, 181-8, and 2579. Helpful secondary literature on these points includes Houlgate (1991), Neuhouser (2000), Pinkard (2002), Pippin (2008), and Wood (1990).
} 
conducted? Unlike Kant, Hegel does not offer an independent criterion (such as the Categorical Imperative) by means of which we can assess institutions and practices. Rather, he offers an immanent critique of the institutions and practices. Such a critique proceeds by showing that institutions or practices are inadequate not in light of some independent standard, but in light of their own standards. The idea is that many institutions and practices are internally inconsistent or unstable, to the extent that once these tensions are revealed the institutions or practices can no longer be maintained. A Hegelian critique proceeds by uncovering these tensions; it shows that there is a disparity between the current social institutions and the ideals that they strive to realize. In other words, a Hegelian critique shows that existing social institutions may be imperfect realizations of their own principles.?

This sketch of Hegel's ethical theory, though exceedingly brief, will be sufficient to bring out two important ways in which the Hegelian view differs from the Kantian view. First, there is the well-known difference in the theories' starting points: Kant begins with the isolated individual who considers whether he can universalize his maxims, whereas Hegel begins with a socially situated individual who reflects on the laws and institutions of her own society.

Second, there is a difference that may be less obvious: normative assessment is carried out in strikingly distinct ways. The Kantian proposes maxims and considers whether they can be willed as

\footnotetext{
${ }^{9}$ Consider an example, which I will borrow from Frederick Neuhouser. Neuhouser asks us to consider the modern democratic system of electing political officials, wherein each citizen is given one vote. He writes, "The practice of 'one person, one vote' embodies an ideal of political equality that is imperfectly realized so long as political campaigns are financed by the "donations" of a few wealthy individuals or corporations" (Neuhouser 2000, 258). In other words, we can see that the current practice of providing each adult citizen with one vote aspires to realize the ideal of political equality: each individual should have an equal say. However, we can also see that our social institutions do not fulfill this ideal perfectly, because wealthy individuals are able to exert more control over the political process than poor individuals. Thus, we can critique the current electoral system by showing that it is an imperfect realization of the ideal to which it aspires. This is an immanent critique, appealing not to some external standard, but to the standards internal to the practice itself.
} 
universal laws. In this sense, Kantianism has a foundationalist structure: Kantians attempt to derive all particular normative claims from one formal principle, the Categorical Imperative. The Hegelian does not attempt to derive normative claims from a formal principle; rather, she begins with a determinate set of principles, embodied in the social institutions of her society, and asks whether these principles are realizations of freedom. (Given Hegel's argument that modern social institutions are designed to realize freedom, the question of whether institutions realize their own principles, and the question of whether they realize freedom, turn out to be one and the same.) So while Kant's theory attempts to derive norms from a formal procedure, Hegel's theory uses a formal criterion (the idea of freedom) not to derive, but to assess norms that are embodied in the society. Accordingly, Hegel's theory has a non-foundationalist structure.

So Hegel's method of justifying normative authority involves scrutinizing the social institutions and practices that we find ourselves with, and showing that they are, or at least aspire to be, realizations of freedom: we can affirm them as institutions and practices in which we realize our own freedom. Asking whether the normative claims embodied in these institutions and practices are justified does not involve showing that they can be derived from some formal criterion, such as the Categorical Imperative. These norms need not be derived from anything at all. Rather, justifying the norms requires showing that, although they are historically contingent, they actualize our freedom.

\section{THE RELATIONSHIP BETWEEN THE NiETZSCHEAN, KANTIAN, AND HEgElian THEORIES OF NORMATIVE AUTHORITY}

To summarize: Kant and Hegel agree that unless there are some constraints on what can be autonomously willed, the attempt to explain normative authority in terms of autonomy is hopeless. However, the prior sections have shown that beyond this point of agreement, the Kantian and Hegelian theories of normative authority diverge in two important ways. First, Kant and Hegel 
disagree on the objects of assessment: whereas Kant argues that we assess maxims of particular actions, Hegel tells us to assess the norms embodied in social institutions and practices. Second, Kant and Hegel disagree on the manner in which norms are to be assessed: Kant claims that we can derive specific moral requirements from the bare idea of freedom, whereas Hegel argues that while a derivation of specific requirements from freedom is impossible, we can use the idea of freedom to assess extant normative structures.

With these results at hand, we can examine the relationship between the Nietzschean, Kantian, and Hegelian theories of normative authority. In this section, I show that Nietzsche's theory incorporates the most appealing features of the Kantian and Hegelian accounts, and also rejects certain problematic aspects of these accounts. ${ }^{10}$ Unfortunately, Nietzsche's resultant theory seems incoherent - in trying to be both Kantian and Hegelian, it runs the risk of collapsing into unintelligibility. However, Section 4 argues that what looks like a problem is actually Nietzsche's deepest insight: we can, in fact, reconcile the most promising aspects of the Kantian and Hegelian theories, and thereby produce a satisfying account of normative authority.

\subsection{NIETZSCHE’S AGREEMENT THAT FREEDOM PLACES DETERMINATE CONSTRAINTS ON WHAT CAN} BE WILLED

One of the most prominent themes in Nietzsche's work is the idea that we must critically assess our values. He famously calls for a "revaluation of all values," writing, "we need a critique of moral values, for once the value of these values must itself be called into question" (GM Preface 6). To revalue a value is to ask whether it merits the status that we accord to it. For example, to revalue egalitarianism would be to engage in a critical assessment of the value that we place on

\footnotetext{
${ }^{10}$ As note 2 indicated, I do not aim to show Nietzsche himself envisioned his project in this way.
} 
egalitarianism. We might begin by asking whether egalitarianism is really valuable, or whether our valuation of egalitarianism is justified, or whether everyone has reason to value egalitarianism.

Interestingly, Nietzsche associates revaluation with the achievement of freedom. Nietzsche's account of freedom has received increased attention in the last decade. Brian Leiter (2002) and other authors have argued convincingly that Nietzsche rejects certain conceptions of freedom, such as the libertarian conception. However, a number of interpreters have shown that Nietzsche has another conception of freedom, as self-determination or autonomy. ${ }^{11}$ Thus, while Nietzsche inveighs against the idea of freedom as an uncaused cause (BGE 21), he praises those who possess the "power of selfdetermination" (GS 347), and he regularly speaks of "evaluating on one's own," being "sovereign," and being "autonomous" (HH Preface 3, GM II.12). He writes that the free individual "is obliged to have recourse to his own law-giving" (BGE 262), and that free individuals enjoy a "constraint and perfection under a law [Geset:] of their own” (GS 290). In a strikingly Kantian moment, he even claims that free individuals are those who "give themselves laws [Sich-selber-Gesetzgebenden]" (GS 335; cf. D 104, GS 117, A 54). ${ }^{12}$

As these passages indicate, Nietzsche links freedom to revaluation. In fact, Nietzsche often treats as interchangeable the "will to self-determination, to evaluating on one's own account, this will to free will" (HH P.3). He argues that if an agent remains under the sway of values that have not been subjected to this process of critical revaluation, then the agent is unfree:

The fettered spirit takes up his position, not for reasons, but out of habit; he is a Christian, for example, not because he has knowledge of the various religions and has chosen between

\footnotetext{
${ }^{11}$ See Gemes (2006), Guay (2002), Janaway (2006), Reginster (2003), and Richardson (2005).

${ }^{12}$ In Zarathustra, Nietzsche gives this an imagistic expression, claiming that the question of whether someone is free can be rephrased in the following way: "Can you give yourself your own evil and your own good and hang your own will over yourself as a law?” (Z I.17).
} 
them... he encountered Christianity... and adopted it without reasons, as a man born in a wine-producing country becomes a wine drinker. (HH I.226)

So it is clear that Nietzsche has a conception of freedom as self-determination, according to which an agent counts as self-determining or autonomous if she acts on values that have been subjected to the process of "revaluation."

But how exactly does Nietzsche conceive of the relationship between freedom and revaluation? Kant thought we could derive specific normative claims from the idea of freedom; Hegel argued that while we cannot do that, we can use freedom to assess extant normative claims. If Nietzsche adopted a view of this form, the link between freedom and revaluation would be clear: revaluation would consist of determining whether particular values conflict with the demands of freedom. Might Nietzsche embrace a view according to which freedom generates constraints on legitimate norms?

It is natural to think that the answer is no; it is common to interpret Nietzsche as a radical subjectivist who argues that there are no constraints on our values and norms. But this interpretation does not withstand scrutiny. In a number of passages, Nietzsche directly asserts that certain values are incompatible with freedom. He quite bluntly states that autonomy is incompatible with the acceptance of traditional moral values, writing that "'autonomous' and 'moral' are mutually exclusive" (GM II.2). This idea is present even in Nietzsche's early works, where he claims that "what characterizes the free spirit is... that he has liberated himself from tradition" (HH I.225). In these passages, Nietzsche makes it clear that the autonomous individual cannot accept the values of traditional morality. ${ }^{13}$ So the demand for autonomy rules out certain values.

Aside from these textual problems with attributing subjectivism to Nietzsche, there is a deeper, philosophical problem. As Section One argued, if the demand for freedom did not impose

\footnotetext{
${ }^{13}$ See also GS 335, GS 347, A 9, A 54, and the closing sections of the Genealogy.
} 
any constraints on what could be valued, then the appeal to freedom could not explain normative authority. Rather than explaining the authority of norms, it would explain norms away: it would reduce norms to whims, for norms would constrain us no more than our whims do.

These considerations suggest that we should take Nietzsche's claim at face value: freedom requires revaluation, and revaluation does indeed place constraints on what can be valued. But how can we make sense of this claim?

Nietzsche cannot be adopting Kant's strategy, for he regards the Kantian arguments linking autonomy to the Categorical Imperative as highly dubious. He condemns

the stiff and decorous Tartuffery of the old Kant as he lures on the dialectical bypaths that lead to his 'categorical imperative' - really lead astray and seduce - this spectacle makes us smile, as we are fastidious and find it quite amusing to watch closely the subtle tricks of old moralists and preachers of morals. (BGE 5)

Here, Nietzsche openly rejects Kant's argument for the Categorical Imperative. Why is this? In several passages, Nietzsche claims that the Categorical Imperative does not generate any content, but merely reiterates the provincial moral beliefs of Kant's day (GS 335, A 12). In other words, Nietzsche alleges that the CI simply enables post hoc rationalizations of existing moral beliefs (Hegel's discussion of property is a perfect example: both the necessity and the abolition of property can be justified in terms of the CI). Moreover, Nietzsche criticizes the structure of the Kantian theory, denying that any moral theory could have the kind of foundationalist structure that Kant envisions. In this light, he writes that Kant and other moral philosophers "make one laugh" with their quest for "a rational foundation for morality." He claims that "seen clearly in the light of day," their theories amount to nothing more than a "scholarly form of good faith in the dominant morality, a new way of expressing it" (BGE 186). 
Rather than attempting to derive morality from some foundational principle, Nietzsche suggests that any substantive moral inquiry will start with a deep scrutiny of the existing values and norms embodied implicitly or explicitly in our social institutions, philosophical theories, and ways of life:

One should, in all strictness, admit what will be needful here for a long time to come, what alone is provisionally justified here: assembly of material, conceptual comprehension and arrangement of a vast domain of delicate value-feelings and value-distinctions [Werthgefüble und Werthunterschiede] which live, grow, beget and perish - and perhaps attempts to display the more frequent and recurring forms of these living crystallizations - as preparation of a typology of morals. To be sure: one has not been so modest hitherto. Philosophers one and all have, with a straight-laced seriousness that provokes laughter, demanded something much higher, more pretentious, more solemn of themselves as soon as they have concerned themselves with morality as a science: they wanted to furnish the rational ground of morality... How far from their clumsy pride was that apparently insignificant task left in dust and mildew, the task of description, although the most delicate hands and senses could hardly be delicate enough for it! (BGE 186)

Mocking the (Kantian) project of furnishing a "rational ground" for morality — a foundational principle from which we can derive a correct moral system-Nietzsche claims that the real task for philosophy is the collection of information about the system of value-feelings and value-distinctions that are present in society. I take it that part of what Nietzsche means to highlight, by using the unusual terms "value-feeling" and "value-distinction" [Werthgefüble und Werthunterschiede] rather than "value," is that our values are not simply manifest in our reflective, conscious judgments, but are ensconced in less reflective forms of relating to the world: in our intuitive reactions, distinctions, ways of classifying or distinguishing actions, and indeed in our feelings. These unreflective 
manifestations of values, Nietzsche suggests, cannot simply be read off the surface of society, or discovered in armchair reflection about what is valuable; rather, Nietzsche claims, discovering our tacit normative commitments requires "the most delicate hands and senses." The following sections continue the discussion of this point and provide illustrations of it: BGE 189-190, for example, trace cultural norms and expectations to concealed, tacit evaluative judgments. BGE 212 sums up this conception of evaluative inquiry; there, Nietzsche writes that philosophers' task is to apply "the knife vivisectionally to the chest of the very virtues of their time," revealing the hypocrisy, contradictions, hidden motives, and defunct ideals at the heart of their society's way of life. In these passages, then, we see that Nietzschean moral inquiry takes the form of an investigation of our cultural practices, expectations, and institutions, bringing to light their implicit principles, motives, and ideals.

So Nietzsche rejects three core elements of the Kantian account: the argument linking autonomy to the Categorical Imperative, the claim that the Categorical Imperative generates determinate content, and the foundationalist structure of Kant's theory. Recall that Section 2 established that Hegel objects to exactly these three aspects of Kant's account. Is it possible, then, that Nietzsche endorses a more Hegelian theory of normative authority? In the next section I argue that Nietzsche does, indeed, adopt certain elements of Hegel's account. Yet Nietzsche's theory is not fully Hegelian; Nietzsche departs from Hegel in two crucial ways.

\subsection{How HEGELIAN COULD NiETZSCHE’S THEORY BE?}

Hegel tells us that it is a mistake to think that we can derive a correct set of ethical norms from some formal principle, such as the Categorical Imperative. Rather, we must always begin with a historically situated set of norms. But rather than just accepting these norms as given, we must 
assess them to see whether they are conducive to the realization of freedom. They can fail by this criterion, and if they do, they must be modified or rejected.

Nietzsche agrees with Hegel's claim that we do not justify norms by deriving them from some formal principle. This is why he mocks the attempt to provide a "rational ground" for morality (BGE 186). Moreover, Nietzsche's critiques of our current values and practices often look quite similar to the Hegelian process of assessing extant norms and values to see whether they live up to their aspirations. To choose a simple example, Nietzsche repeatedly argues that our practice of compassion fails to live up to its own aims: while compassion aims to aid the object of the compassion, Nietzsche contends that attention to the psychology of compassion will reveal that it harms both the compassionate person and the object of her compassion. ${ }^{14}$ If this were correct, then we would have reason to reconsider the value placed on compassion. Many of Nietzsche's critiques can profitably be read in this fashion, for they often proceed by bringing to light hidden contradictions and inconsistencies in our practices and our dominant values. In other words, many of Nietzsche's critiques consist in showing, as he puts it, that "the motives of this morality stand opposed to its principle" (GS 21).

Nietzsche therefore seems to be in agreement with Hegel's two departures from Kant: namely, Hegel's claim that we assess norms embodied in social institutions and practices, and Hegel's anti-foundationalist method of critiquing norms. However, a closer examination reveals that Nietzsche and Hegel part company on this last point. There are two important differences: Nietzsche and Hegel disagree on how far-reaching the critique of modern norms will be, and they also disagree on whether the critique appeals to some principle that is external to the currently dominant set of norms.

${ }^{14}$ For a helpful discussion of this point, see Reginster (2006, 186ff.). 
Start with the first point. For Hegel, the critique is restricted to determining whether our social institutions and laws live up to their aspirations: while they aspire to be realizations of human freedom, they can fall short of that ideal, and therefore require modification. Nietzsche, however, pursues a far more radical critique: he wants to show that the very ideals to which these institutions aspire must be reassessed. As he puts it in the Genealogy,

What if a symptom of regression were inherent in the 'good', likewise a danger, a seduction, a poison, a narcotic, through which the present was possibly living at the expense of the future? [...] So that precisely morality would be to blame if the highest power and splendor actually possible to the type man were never in fact attained? So that precisely morality were the danger of dangers? (GM Preface 6)

In his own work, Nietzsche critiques some of our most cherished values. To choose just a few examples: he complains that the effects of "liberal institutions" are "known well enough: they undermine the will to power" (TI ix.38). He writes, "well-being as you understand it - that is no goal, that seems to us an end, a state that soon makes man ridiculous and contemptible" (BGE 225). What "has been called morality," Nietzsche insists, will "deprive existence of its great character" (EH iv.4). And he warns that "our weak, unmanly social concepts of good and evil and their tremendous ascendancy over body and soul have finally weakened all bodies and souls and snapped the selfreliant, independent, unprejudiced men, the pillars of a strong civilization” (D 163; cf. BGE 62, A 5). Thus, Nietzsche clearly believes that modern values are fundamentally misguided.

This brings us to the second point. Hegel and Nietzsche's disagreement on how extensive the critiques of modern norms will be reflects a deeper disagreement concerning the way in which the critique is conducted. Whereas Hegel engages in immanent critiques, showing that institutions fail to realize their own ideals, Nietzsche argues that in order to carry out an adequate critique of 
existing norms, we need to employ some evaluative standard external to the norms themselves. As Nietzsche puts it,

'Thoughts about moral prejudices', if they are not meant to be prejudices about prejudices, presuppose a position outside morality. (GS 380)

Unlike Hegel, Nietzsche thinks that we must do far more than simply locate the values to which our practices aspire, and assess their conformity to these values. Nietzsche claims that we need to uncover a standard that can be used to evaluate the basic aspirations of these institutions. ${ }^{15}$ This marks a profound difference between the Hegelian and Nietzschean accounts of normative authority.

\subsection{A THEORY THAT IS BOTH KANTIAN AND HEGELIAN?}

Just as Kant's theory can seem too attenuated, too contentless, Hegel's can seem too concrete, too anchored in the particularities of the current social situation. Whereas Hegel wants to show that the current set of social institutions is more or less correct, and strives toward an appropriate ideal, Nietzsche wants to levy a much more radical critique: he aims to show that the basic values informing these social institutions, the basic values that these institutions strive to realize, must be reassessed.

And yet, like both Kant and Hegel, Nietzsche wants the authority of norms to be grounded in the fact that they are, in some sense, self-imposed. So Nietzsche's view seems to hover uneasily between Kant's and Hegel's, in that he endorses all of the following claims:

1. The demand for autonomy produces determinate constraints on what is to be valued.

${ }^{15}$ Thus, in BGE 211, Nietzsche claims that Kant and Hegel merely adopt the dominant values of their times, and "identify them and reduce them to formulas." He contrasts this with the work of "real philosophers." Nietzsche argues that real philosophers must do more than simply accept and codify the dominant value; they must "apply the knife of vivisection to the virtues of their time" (BGE 212), and create new values. 
2. However, we do not justify values by showing that they are derived from or entailed by the demand for autonomy.

3. Rather, we use autonomy to assess our current values.

4. Yet autonomy somehow permits, and indeed requires, a radical critique of these current values. ${ }^{16}$

Is there a way of making sense of these claims, which might appear to be in conflict with one another? The next section argues that there is.

\section{NIETZSCHE'S SOLUTION TO THE PROBLEM OF NORMATIVE AUTHORITY}

What looks like a problem is actually one of Nietzsche's deepest insights: the four claims mentioned above can be rendered consistent. The solution lies in recognizing that when Nietzsche speaks of revaluation and freedom, he often incorporates a third concept as well: will to power $W$ ille zur Macht]. This is the concept that enables Nietzsche to produce a novel account of normative authority, which reconciles the seemingly incompatible elements of the Kantian and Hegelian theories.

Nietzsche draws two connections between will to power, autonomy, and revaluation. First, he argues that the "principle of revaluation" or the "standard by which the value of moral evaluation is to be determined" is "will to power" (WP 391/KSA 12:2[131]). ${ }^{17}$ In other words, revaluation is to be conducted in terms of will to power. Second, Nietzsche claims that we achieve freedom to the extent that we manifest will to power. For example, he identifies the "instinct for freedom" with the

\footnotetext{
${ }^{16}$ To recap: Kant and Hegel both endorse versions of (1). Kant denies (2), whereas Hegel accepts (2). Kant and Hegel both accept (3), but interpret the requirement in different ways. Kant and Hegel both deny (4).

${ }^{17}$ He makes the same point elsewhere, writing, "what is good? Everything that heightens in human beings the feeling of power, the will to power, power itself' (A 2). Here, he again suggests that the criterion of assessment for other values is will to power.
} 
"will to power" (GM II.18), he claims that a free will is equivalent to a "strong" will, i.e., a will that manifests will to power (BGE 21), ${ }^{18}$ and, in a section entitled "my conception of freedom," he claims that freedom is measured according to the degree of power expressed by an individual. ${ }^{19}$

Taking these claims into account, I submit that the basic structure of Nietzsche's theory is as follows: an agent is autonomous if she acts on values that have been "revaluated" or critically assessed; this critical assessment is conducted in terms of will to power; so, an agent is autonomous if she acts on values that are consistent with—but not derived from-will to power. This is what Nietzsche intends when he claims that freedom should be understood in terms of will to power.

The question, of course, is what all of this means. What is will to power? Why must

revaluation be conducted in terms of will to power? The following sections address these questions. This will enable us to see how Nietzsche's theory manages to combine the most appealing features of the Kantian and Hegelian accounts of normative authority, while avoiding some of their potential problems.

\subsection{WHAT IS WILL TO POWER?}

To begin, we need to understand what Nietzsche means by will to power. It is important not to be misled by the surface connotations of the term "power" [Macht]. In ordinary discourse, the claim that people will power would suggest that they strive to dominate, tyrannize, and subjugate

\footnotetext{
${ }^{18}$ The surrounding context makes it clear that Nietzsche's talk of strong and weak wills should be understood in terms of will to power, for the two sections following this remark discuss his notion of will to power. BGE 22 introduces the notion of will to power; BGE 23 claims that psychology is the "path to the fundamental problems," and that psychology should be understood in terms of "the doctrine of the development of the will to power."

${ }^{19}$ In this passage, Nietzsche claims that freedom is measured "according to the resistance which must be overcome." Below, I will argue that Nietzsche associates will to power with overcoming resistance; accordingly, this passage associates freedom with degree of will to power.
} 
others. But this is not what Nietzsche has in mind. Power is a term of art, for Nietzsche; he gives it a special sense.

Nietzsche characterizes will to power in language that seems deliberately vague; he associates power with a family of terms, such as "giving form," "expanding," "imprinting," "overcoming," "mastering," and "shaping." 20 He writes that will to power is "the will's forward thrust and again and again becoming master over that which stands in its way" (WP 696/KSA 13:11[75]). Moreover, Nietzsche does not attribute a specific end to those who will power; he claims that the will to power is manifest in activities that are directed at disparate ends. For example, Nietzsche tells us that human beings will power by engaging in activities as diverse as pursuing knowledge, creating art, participating in athletic endeavors, and writing novels (cf. GM II.17-18 et passim).

In order to see exactly what will to power $i s$, we will need to determine what these characterizations of will to power have in common. Although Nietzsche's descriptions tend to be rather elliptical, he does repeatedly and insistently emphasize two points about will to power.

First, Nietzsche claims that will to power can never enjoy permanent satisfaction, but instead involves perpetual striving.

The wish to preserve oneself is the symptom of a condition of distress, of a limitation of the really fundamental instinct of life which aims at the expansion of power, and wishing for that frequently risks and even sacrifices self-preservation. (GS 349)

A condition once achieved would seem to be obliged to preserve itself-Spinoza's law of "self-preservation" ought really to put a stop to change: but this law is false, the opposite is true. It can be shown most clearly that every living thing does everything it can not to preserve itself but to become more- (WP 688/KSA 13:14[121])

${ }^{20}$ GM II.18, GS 349, BGE 259, Z II.12, WP 696/KSA 13:11[75]. 
In contrasting the desire to "preserve oneself" — that is, the desire to abide in one's current statewith the will to power, Nietzsche emphasizes that will to power involves perpetual striving. ${ }^{21}$

Second, will to power manifests itself as a particular form of striving: striving for resistances or obstacles. Consider the following passages:

The will to power can manifest itself only against resistances; therefore it seeks that which resists it... (WP 656/KSA 12.9[151])

The will is never satisfied unless it has opponents and resistance. (WP 696/KSA 13:11[75]) When Nietzsche refers to "resistances," he means impediments or challenges to one's ends. The structure to which Nietzsche is drawing attention is clearest in the case of competitive or skillful endeavors, such as sports and games. Consider activities such as marathon running or chess playing. Part of the point of these activities is that they are challenging, introducing obstacles or difficulties that must be overcome. One tries to run twenty-six miles, rather than twenty-six feet, because the former is so difficult and the latter so easy; analogously, one plays chess (and other games) precisely because one wants to encounter a challenging task, which requires skill and ingenuity to complete successfully. In short, agents who choose to engage in marathon running and chess playing seem actively to seek obstacles or resistances, in order to surmount them. In the passages quoted above, Nietzsche makes it clear that willing power involves doing just this.

Of course, one does not want these challenges or resistances to serve as permanent impediments to one's ends; rather, one wants to overcome the impediments. As Nietzsche puts it, the agent seeks to "again and again [become] master over that which stands in its way" (WP 696/KSA 13:11[75]. For example, the marathoner does not want to confront the pain and difficulty of

${ }^{21}$ Compare Alexander Nehamas's claim that "willing as an activity does not have an aim that is distinct from it; if it can be said to aim at anything at all, that can only be its own continuation. Willing is an activity that tends to perpetuate itself, and this tendency to the perpetuation of activity... is what Nietzsche tries to describe by the obscure and often misleading term 'will to power"' $(1985,79)$. Heidegger concurs: "will to power is will to will” (1979, vol. I, 37). 
running twenty-six miles, and find herself incapable of overcoming them, collapsing after five miles; rather, she wants to hold herself to the course of action despite the challenges involved in doing so. She wants to overcome these obstacles, by completing the race. This is why the runner sets herself a goal that is achievable, albeit only with great difficulty. She does not set herself an impossible task such as running two hundred miles, nor does she set herself a less challenging task such as running five miles; she sets herself a challenging-yet-achievable task. (To return to the other example, chess players typically do the same thing: a typical chess player will seek to compete with players who are at similar or slightly superior levels of skill, rather than to play against opponents who are easily defeated or virtually undefeatable.)

In sum, Nietzsche seems to identify willing power with the activity of perpetually seeking and overcoming resistance to one's ends. I therefore conclude that, as Bernard Reginster puts it, "will to power, in the last analysis, is a will to the very activity of overcoming resistance" (Reginster 2006, 127)..$^{22}$

It is important to notice that power is not a first-order end; rather, an agent wills power in the course of pursuing some other, more determinate end, such as completing a race or finishing a game. We might express this point by saying that will to power is a higher-order aim. In order to will power, one must aim at a determinate first-order goal, such as running or checkmating one's opponent. Will to power does not compete with these determinate goals; rather, it modifies the way in which these goals are pursued. As John Richardson helpfully puts it, will to power isn't a claim about what we will; it is a claim about how we will (Richardson 1996, 21).

\footnotetext{
${ }^{22}$ Reginster (2006) argues for this characterization at length. My analysis of will to power is indebted to his work.
} 


\subsection{WiLL TO POWER AS A CLAIM ABOUT THE ESSENTIAL NATURE OF WILLING}

Now we know what will to power is. But there is another central component to Nietzsche's account, which we will need to understand in order to uncover the connection between will to power and freedom. This is Nietzsche's claim that every action manifests will to power.

When we scrutinize our own actions, Nietzsche believes that we find that our most ubiquitous source of motivation, which lies behind all that we do, is will to power. Nietzsche often expresses this point by claiming that will to power is the "essence" [Wesen, Essenz] of willing. There are a number of passages in the published works and unpublished notebooks that make this point. To choose just two:

All 'purposes,' 'aims,' 'meaning' are only modes of expression and metamorphoses of one will that is inherent in all events: the will to power. To have purposes, aims, intentions, willing in general, is the same thing as willing to be stronger, willing to grow_-and, in addition, willing the means to this. (WP 675/KSA 13.11[96])

Everything that happens out of intentions can be reduced to the intention of increasing power. (KSA 12.2[88])

In these quotations, Nietzsche claims that every episode of willing, or every action, aims at power. ${ }^{23}$

As noted in the last section, will to power is a higher-order aim: an agent pursues power in the course of pursuing some other, more determinate end. So Nietzsche's claim that every action aims at power amounts to this: whenever a person wills an end, this episode of willing has a certain

\footnotetext{
${ }^{23}$ For other passages in which Nietzsche claims that will to power is an essential feature of action, see especially GS 349, GM III, WP 688/KSA 13.14[121], WP 689/KSA 13.14[81], and WP 702/KSA 13.14[174].
} 
structure. It consists not only in the aim of achieving some end, but also in the aim of encountering and overcoming resistance in the pursuit of that end. ${ }^{24}$

The notion that we strive to encounter and overcome resistance is most plausible in relation to competitive or skillful actions, but Nietzsche argues that this striving is a feature of all human actions. His argument for this claim is complex, and I lack the space to reconstruct it here. For present purposes, it will be sufficient to note that Nietzsche's argument takes the following form. First, he argues that all human actions are motivated by a distinctive kind of psychological state, the drive (Trieb). Drives differ from desires in that while many desires are dispositions to realize some determinate end, drives are dispositions to engage in characteristic forms of activity. The aggressive drive, for example, does not motivate us to achieve any particular goal, but merely to engage in aggressive activity. For this reason, Nietzsche argues that any action that is motivated by a drive will have a higher-order aim of encountering and overcoming resistance: the drive motivates us to engage in characteristic patterns of activity, and manifesting these patterns of activity involves continual overcoming of the resistances to that activity. ${ }^{25}$ If Nietzsche is correct that all human activities are drive-motivated (obviously, no small claim), then it follows that all human actions have a higher-order aim of encountering and overcoming resistance. In Nietzsche's terminology, this is equivalent to the claim that all human actions manifest will to power. ${ }^{26}$

\footnotetext{
${ }^{24}$ This is why Nietzsche says that "all 'purposes,' 'aims,' 'meaning' are only modes of expression and metamorphoses of one will that is inherent in all events: the will to power" (WP 675/KSA 13.11[96]; emphasis added). He is not claiming that every goal is a means to power; rather, he is claiming that whenever we will any goal at all, we express will to power by also willing resistance to that goal. ${ }^{25}$ More precisely, Nietzsche argues that what it is for something to aim at power is for it to be drivemotivated. Will to power is not an independent drive, but a description of the structure of drivemotivated actions.

${ }^{26}$ Let me mention three important qualifications, which I discuss at length in Katsafanas (2013a). First, Nietzsche argues that we can aim at X without realizing that we aim at X, indeed without the possibility of aiming at $\mathrm{X}$ ever entering our conscious reflection. So his claim that every action aims at power is not contradicted by the obvious fact that many individuals do not understand their actions as having this aim. Second, Nietzsche contends that many actions manifest the aim of
} 
Nietzsche's claim that every action aims at power is, of course, highly controversial.

However, our task here is not to assess this aspect of Nietzsche's account, but to determine the structure of Nietzsche's theory of normative authority. Thus, for present purposes, let's grant the claim and ask whether Nietzsche can use it to generate a compelling account of normative authority.

\subsection{WHY DOES FREEDOM REQUIRE REVALUATION IN TERMS OF POWER?}

Suppose Nietzsche can establish that every action aims at power. Given this premise, Nietzsche is able to show that revaluation must be conducted in terms of will to power. His argument can be reconstructed as follows:

i. An agent is self-determining iff she acts on values whose authority has been critically assessed.

ii. In order to critically assess a value, one must determine whether the value minimizes conflicts with will to power. Those values that minimize these conflicts are acceptable, whereas those that do not are to be rejected.

iii. Therefore, if an agent is self-determining, then she acts on values that minimize conflict with will to power.

Premise (i) was defended in Section 3.1. Explicating and defending the crucial premise (ii) is the task of this section.

As I mentioned at the beginning of Section 4, Nietzsche's commitment to premise (ii) is clear; he repeatedly emphasizes that the "standard by which the value of moral evaluation is to be determined" is "will to power" (WP 391/KSA 12:2[131]; cf. A 2, A 6, WP 674/KSA 13:11[83]).

power only in a halfhearted, conflicted, or distorted fashion. Third, Nietzsche is not claiming that will to power is our strongest aim, nor is he claiming that it is typically decisive in determining what we will do. On the contrary, will to power has only a minor influence on most of our actions. It is not, so to speak, the strength of this motive that renders it important; it is the motive's omnipresence, which shapes our actions in a gradual and aggregative fashion. 
Nietzsche suggests that any value that conflicts with will to power should be rejected. But how does Nietzsche argue for this claim? I submit that there are several steps.

First, Nietzsche seems to rely on the assumption that aims are reason-providing. More precisely: if you have an aim, you have a reason to fulfill it. ${ }^{27}$ This is a relatively uncontroversial claim; even the most minimal accounts of practical reason, including most variants of the Humean account, accept this claim. ${ }^{28}$

Second, it follows that if an aim is present in every episode of action, then whenever an agent acts she will have a (pro tanto) reason to fulfill this aim. So, given Nietzsche's claim that all actions aim at power, whenever a human being acts, she will have a reason to seek power.

Third, notice that these will-to-power-derived reasons will sometimes conflict with the reasons springing from our other aims and values. Take a simple example: suppose an individual values a form of complacency. This individual believes that it is valuable to be content with what one already has; one should not seek further accomplishments. This value clearly conflicts with will to power. As the prior sections argued, to will power is to aim at resistances and challenges. So we have a straightforward conflict: valuing complacency involves judging that there is reason not to confront challenges, but aiming at power commits us to the claim that there is reason to confront challenges. If an agent accepts the value of complacency, then he will be committed to contradictory propositions about how to act.

\footnotetext{
${ }^{27}$ More carefully, we should say that if you have an aim, you have a pro tanto reason to fulfill it. A pro tanto reason is a reason that has some weight, but nonetheless may be outweighed by other reasons. For example, if I aim to get to my office within ten minutes, and if doing so requires driving at ninety miles per hour, I have a pro tanto reason to drive at this speed. Nevertheless, this reason is outweighed by reasons provided by my other aims, such as my aims of driving safely and minimizing potential harm to others.

${ }^{28}$ There is a complication: some philosophers, reluctant to count seemingly immoral aims as generating reasons, argue that we should express the relevant normative claim differently. It is not that aims provide us with reasons; rather, if we have an aim, then we have reason either to fulfill the aim or to give up the aim. For accounts of this form, see for example Broome (1999). This point does not affect the argument given above, so I ignore it in what follows.
} 
What does this tell us about the value of complacency? It is clear enough that, in presenting will to power as the standard of revaluation, Nietzsche wants us to reject any value that generates conflicts of this form. In making this claim, Nietzsche relies upon the inescapability of will to power. If he is correct in arguing that will to power is an essential feature of action, then this aim cannot be reassessed or altered; the fact that every action aims at power generates an inescapable, pro tanto reason to seek power. However, other aims and values can be reassessed and altered. For example, we could — and many do_-regard complacency as not valuable, or even as disvaluable. So Nietzsche's point is simple: when there is a conflict between the will to power and some other value or aim, the only way in which we can alleviate the conflict is by modifying the other value or aim. ${ }^{29}$

I submit that Nietzsche takes these points to establish (ii). Given (ii), the conclusion follows: if an agent is self-determining, then she acts on values that minimize conflict with will to power. In short: freedom requires critical assessment of one's values, and this critical assessment consists in revaluing one's values in light of power.

\subsection{The STRUCTURE OF NiETZSCHE'S THEORY}

I have only been able to sketch the structure of Nietzsche's theory here; I address the arguments for the theory elsewhere. ${ }^{30}$ Suppose, though, that the theory is defensible. We can then

\footnotetext{
${ }^{29}$ Notice that on Nietzsche's account every action aims at power. Thus, even an agent who values complacency will be aiming at power, albeit in a conflicted, distorted, or halfhearted manner. Part of what it is to become free, on Nietzsche's theory, is to render this aim of power less conflicted and distorted; to do this, one minimizes conflicts amongst one's aims. This is why Nietzsche often associates freedom with unity amongst one's motivational states.

${ }^{30}$ For an account of drives, see Katsafanas (2013b); for the argument that if human actions are drive-motivated, then human beings are ineluctably committed both to willing power and to treating power as a standard of success for action, see Katsafanas (2013a); for the connection between freedom and lack of conflict amongst one's reasons and aims, see Katsafanas (in progress).
} 
ask what the consequences would be: what kind of explanation of normative authority would the theory generate?

We saw that Nietzsche's theory incorporates four central claims, which I will repeat here:

1. The demand for autonomy produces determinate constraints on what is to be valued.

2. However, we do not justify values by showing that they are derived from or entailed by the demand for autonomy.

3. Rather, we use autonomy to assess our current values.

4. Yet autonomy somehow permits, and indeed requires, a radical critique of these current values.

The interpretation that I have proposed does, in fact, reconcile these claims.

First, notice that the demand for autonomy entails that we must revalue our values in light of will to power. So the demand for autonomy does generate a determinate constraint on permissible values: we are to adopt those values that minimize or eliminate conflict with will to power. Thus, condition (1) is fulfilled.

Second, on Nietzsche's view, we do not justify the authority of a value by showing that it derives from or is entailed by autonomy. Nietzsche does argue that one normative principle can be derived from the features of autonomous willing: the claim that we have reason to will power. But it should be clear that we are not going to be able to derive much additional content from this claim. For example, there is no way of moving from the idea that we aim to encounter and overcome resistance to the idea that we should not lie, or that we should not murder. On the contrary, lying and murdering are ways_-possibly quite good ways_of willing power. Fortunately, Nietzsche's will to power doctrine is not meant to function as a foundational principle from which we derive all other normative claims. Rather, as the prior sections explained, will to power is intended to serve as a "principle of revaluation." That is, the will to power generates a standard in terms of which we are 
to assess all other values. So Nietzsche grounds one normative principle in facts about our agential nature, and uses this principle not to derive, but to assess, the other values that we embrace. In this respect, Nietzsche's theory looks more Hegelian than Kantian: rather than attempting to derive our values from a formal principle, we use a formal principle to assess our current, historically contingent set of values. The resultant theory does not have a foundationalist structure, of the sort that Nietzsche clearly denounces; but it does give one value a privileged status, and it uses that value as a criterion or principle of revaluation. Thus, Conditions (2) and (3) are fulfilled.

Finally, the fact that power has a privileged status enables us to mount a radical critique of our current set of values and social institutions - a critique that may reveal them not merely to fall short of their own ideals, but to be deeply misguided in the goals they strive to realize. Power's privileged status gives us, as Nietzsche puts it, "a position outside morality," in terms of which we can reassess even our most basic values (GS 380). Thus, condition (4) is fulfilled.

So my proposed interpretation of Nietzsche's theory does, in fact, fulfill the four conditions. Nietzsche's theory incorporates the most appealing features of the Kantian and Hegelian views: it is a non-foundationalist ethic, which nevertheless explains normative authority through an appeal to autonomy, and allows for a radical critique of our current values. And the importance of this result extends beyond questions of Nietzsche interpretation: if the argument is correct, then we can ground normativity in an ineluctable aim, assess other norms and values for consistency with this aim, and thereby generate a non-foundationalist, autonomy-based ethical theory.

\section{Conclusion}

I have argued that will to power is the red thread linking Nietzsche's claims about revaluation and freedom. Appreciating this point enables us to see how Nietzsche can reconcile seemingly incompatible elements of the Kantian and Hegelian accounts of normative authority. 
Let me summarize the results. First, Kant, Hegel, and Nietzsche share a common foundational idea: they believe that the authority of normative claims can be justified only by showing that these norms are, in some sense, self-imposed or autonomous. In other words, no realist construal of norms would be satisfactory; any legitimate norm must have its source in us.

However, this project gives rise to a problem: does the injunction "be autonomous!" impose any substantive constraints on the content of norms? If not, we face the charge that Hegel levies against Kant: the injunction has no content, so nothing could count as not fulfilling the demand. Kant thinks he has a solution to this problem: he argues that autonomy yields commitment to the Categorical Imperative, and that the Categorical Imperative does, in fact, generate determinate normative content. Yet Hegel, and later Nietzsche, deny that Kant succeeds: they contend that the Categorical Imperative is just an empty formalism, which either merely reiterates the moral demands of Kant's society, or generates no content whatsoever.

This leads Hegel to his theory of Sittlichkeit, or ethical life. According to Hegel, we do not derive moral content from the formal idea of freedom. Rather, we use the idea of freedom to assess existing social institutions and practices, seeking to determine whether they are realizations of freedom. While there are many differences between Hegel and Nietzsche on this score, I have argued that Nietzsche's theory incorporates the Hegelian claim that we use the idea of freedom to assess existing moral norms. ${ }^{31}$

However, unlike Hegel, Nietzsche believes that one norm can be extracted from the bare idea of freedom, independently of any facts about the particular system of values, practices, and institutions that the individual inhabits. This norm is will to power. Its connection to freedom and

\footnotetext{
${ }^{31}$ Perhaps the most significant difference between Hegel and Nietzsche-a difference that I lack the space to investigate here-lies in the importance, for Hegel, of mutual recognition. While this notion plays a crucial role in Hegel's account of selfhood and normativity, Nietzsche rarely mentions it.
} 
its independence from extant social norms gives it a position outside of our current ethical norms, making possible a radical critique of these norms.

Nietzsche's theory therefore incorporates seemingly disparate elements of the Kantian and Hegelian accounts, generating a unique and, I believe, philosophically fruitful solution to the problem of normative authority. Indeed, if one can be pardoned for a Hegelian expression, Nietzsche's larger project can be profitably viewed as an attempt to sublate the Kantian and Hegelian accounts of normative authority, showing that each is a partial and one-sided truth that finds correct expression in Nietzsche's own theory. 


\section{REFERENCES}

Abbreviations of Kant's Works:

C1 Critique of Pure Reason, eds. P. Guyer and A. Wood (Cambridge University Press, 1999)

C2 Critique of Practical Reason, trans. W. Pluhar (Hackett, 2002)

G Groundwork of the Metaphysics of Morals, ed. M. Gregor (Cambridge University Press, 1998)

Abbreviations of Hegel's Works:

PhG The Phenomenology of Spirit, trans. A.V. Miller (Oxford, 1979)

PR The Philosophy of Right, trans. A. White (Focus, 2002)

VG Vorlesung über die Philosophy des Geistes 1827-8, ed. B. Tuschling (Felix Meiner, 1994)

Abbreviations of Nietzsche's Works:

A The Antichrist, trans. W. Kaufmann (Viking, 1954)

BGE Beyond Good and Evil, trans. Kaufmann (Modern Library, 1968)

D Daybreak, trans. R.J. Hollingdale (Cambridge University Press, 1982)

EH Ecce Homo, trans. Kaufmann (Modern Library, 1968)

GM On the Genealogy of Morality, trans. Kaufmann (Modern Library, 1968)

GS The Gay Science, trans. Kaufmann (Vintage, 1974)

HH Human, All Too Human, trans. Hollingdale (Cambridge University Press, 1986)

KSA Kritische Studienausgabe in 15 Bänden, eds. G. Colli and M. Montinari (Walter de Gruyter, 19671977)

TI Twilight of the Idols, trans. Kaufmann (Viking, 1954)

WP The Will to Power, trans. Kaufmann and R.J. Hollingdale (Vintage, 1967)

Z Thus Spoke Zarathustra, trans. Kaufmann (Viking, 1954) 
Brobjer, T. (2008), Nietzsche's Philosophical Context. Urbana-Champaign, IL: University of Illinois Press.

Broome, J. (1999), “Normative Requirements,” Ratio 12(4): 398-419.

Dudley, W. (2007), Hegel, Nietssche, and Philosophy: Thinking Freedom. Cambridge: Cambridge University Press.

Gemes, K. (2006), "Nietzsche on Free Will, Autonomy and the Sovereign Individual,” Aristotelian Society Supplementary Volume, 80: 321-338.

Heidegger, M. (1979), Nietssche, trans. D. F. Krell. New York: Harper and Row.

Houlgate, S. (1991), Freedom, Truth and History: An Introduction to Hegel's Philosophy. New York: Routledge.

--- (2004), Nietssche, Hegel, and the Criticism of Metaphysics. Cambridge: Cambridge University Press.

Janaway, C. (2006), "Nietzsche on Free Will, Autonomy and the Sovereign Individual," Aristotelian Society Supplementary Volume, 80: 339-357.

Katsafanas, P. (2013a), Agency and the Foundations of Ethics: Nietasche Constitutivism. Oxford: Oxford University Press.

--- (2013b), “Nietzsche’s Philosophical Psychology,” in The Oxford Handbook of Nietæsche, edited by John Richardson and Ken Gemes, 727-755. Oxford: Oxford University Press, 2013.

--- (in progress), The Nietzschean Self: Agency and the Unconscious.

Korsgaard, C. (1996), Creating the Kingdom of Ends. Cambridge: Cambridge University Press. Leiter, B. (2002), Nietzsche on Morality. London: Routledge.

Nehamas, A. (1985), Nietzsche: Life as Literature. Cambridge, MA: Harvard University Press.

Neuhouser, F. (2000), Foundations of Hegel's Social Theory. Cambridge, MA: Harvard University Press. 
Pinkard, T. (2002), German Philosophy 1760-1860: The Legacy of Idealism. Cambridge: Cambridge University Press.

Pippin, R. (1997), Idealism and Modernism. Cambridge: Cambridge University Press.

--- (2008), Hegel's Practical Philosophy: Rational Agency as Ethical Life. New York: Cambridge University Press.

Reginster, B. (2003), "What is a Free Spirit? Nietzsche on Fanaticism," Archiv für Geschichte der Philosophie, 85: 51-85.

--- (2006), The Affirmation of Life. Cambridge, MA: Harvard University Press.

Richardson, J. (1996), Nietzsche’s System. New York: Oxford University Press.

--- (2005), “Nietzschean and Kantian Freedoms,” International Studies in Philosophy, 37: 149-162.

Wood, A. (1990), Hegel's Ethical Thought. Cambridge: Cambridge University Press. 